\title{
INCOME AND QUALITY OF LIFE INFLUENCE ON CITIZENS' PARTICIPATION IN ACTIVITIES OF LOCAL GOVERNMENTS IN LATVIA
}

\author{
Baiba Šavriṇa ${ }^{1}$, Lilita Seimuškāne ${ }^{2}$
}

\begin{abstract}
The aim of the paper is to analyse the factors influencing the citizen participation in activities of local governments in relation to quality of life in Latvia. The use of the CLEAR model, elaborated by a group of British researchers under guidance of Gerry Stoker, shows the possibilities of participation and engagement of citizens based on theoretical aspects. Latvia, as a member state of the EU, needs to develop and to involve more citizens in different social activities, since it has comparatively small experience in democratic processes due to its past of 50 years being a part of another country - the Soviet Union. The opportunities to participate in the European Parliament's election and to promote the resolution of common issues or questions specific for the country can be one of the ways for expressing life priorities. Historical heritage is still influencing the priorities of population, such as changes in income level and possibilities to increase the quality of life, have a strong impact on the perception of citizens. By using the concept of a welfare state and a welfare economy, it is possible to explain the enlargement of areas of citizens' interaction. Unbalanced regional development with a huge impact on the capital city in the national economy and in the number of inhabitants concentrated in Riga that amounts to a third of the total population with important differences in income level and quality of life has profound influence on other regions and the interests of inhabitants to participate in local governmental activities. The factors, which affect this engagement, are analysed by using primary and secondary data. The main conclusions are: 1) there is more active citizens participating in the activities of local government than in the election of the European Parliament due to faster and more visible results in solving problems, 2) the global financial crisis strongly affected the participation level, the changes of economic conjuncture have an important impact on the participation of citizens 3) imbalance in regional development is reflected by the level of participation, since there is a higher level of participation in economically favourable regions.
\end{abstract}

JEL Classification Numbers: I31, E71, H75, R11, R13; DOI: http://dx.doi.org/10.12955/cbup.v6.1193

Keywords: income, quality of life, local government, citizens' participation, Latvia

\section{Introduction}

Voter turnout and the examination of motivation factors in elections began with participation research in the $40 \mathrm{~s}$ and $50 \mathrm{~s}$ of the $20^{\text {th }}$ century. This was followed by interest in the activity of the residents during the period between elections and by attempts to structure participation after political or civic features. An increase of the role of the public administration in the distribution of public benefits emphasized the activity of different groups of interest and pressure in the process of decision-making. On one hand, these expanded conceptual limits of participation were deep-rooted in new expressions of citizens' participation, but on the other hand, the limits among political and civic, individual and collective activities became more uncertain. Studies of participation types and forms became topical. Attempts to find answers to reasons that define the choice of the residents to participate or not participate, developed a powerful research direction that was related to the study of diverse factors of participation.

The aim of this paper is to analyse the factors influencing the participation of citizens in activities of local governments in relation to the quality of life in Latvia. The history of citizen participation in Latvia is smaller than in developed countries due to the interrupted development of democracy during the 50 years within Soviet Union.

Participation in democracy at the level of local governments means that for the residents there are preconditions caused, rights strengthened, and opportunities created to directly affect decisions of local governments in the questions that related to the local community and which affect their life. This means that citizens of a local government act not only as voters in local elections at specific periods but also have permanent opportunities to participate in the consideration of different questions outside elections which are provided to them as full-fledged members of the community. A role of participating citizen is also emphasised by the European Charter of Local Self-Government, with its preamble pointing out that its text in based on the rights of the citizens to participate in governance of the public affairs (European Charter of Local Self-Government, 1985).

\section{Definitions and Typologies of Political Participation}

The understanding of political participation has changed its conceptual limits. This was affected both by a growing role of the public administration and its policy in certain democracy development stages,

\footnotetext{
${ }^{1}$ University of Latvia, Faculty of Business, Management and Economics, baiba.savrina@lu.lv

${ }^{2}$ University of Latvia, Faculty of Business, Management and Economics, lilita.seimuskane@gmail.com
} 
as well as by the gradual merging and disappearance of strict borders between political and nonpolitical activities, both public and private.

When pointing on different interpretations of political participation, Jan van Deth, a researcher at University of Mannheim, mentions the following common features that characterize the essence of political participation (Van Deth, 2001):

- In the process of political participation, an individual from the society represents him/herself as a resident; and he/she in this status cannot act as a politician or official who receives a remuneration for his/her work;

- Political participation becomes apparent as an organized activity or action that can be observed and measured. The process of watching a television news broadcast and the resulting discussion with neighbours is not an expression of political participation;

- Activities of the population in this process of political participation should be voluntary, and the population needs to be the initiators. Such activities cannot be triggered or controlled by the political elite;

- Forms of political participation of citizens should be legal, i.e. complying with legal norms;

- Political participation meets the activities of public authorities and their decisions or the political system at its widest. This does not mean only separate levels of administration and specific operational frameworks, such as parliamentary legislation or the national government.

Sidney Verba et al. (1978), an American researcher, holds a different opinion regarding the conceptual borders of participation. In the participation process, he was interested in the activities with the aim to affect the government, by either affecting the selection of government officials or affecting the choice made by the officials, respectively, in affecting the politics rather than its implementation. In the typology of political participation, Verba expresses four dimensions:

- Voting in elections;

- Campaign activities (membership to political parties or organizations, activities within them, and money donations);

- Contacting politicians, officials;

- Cooperation in communal activities that are important for the local community and oriented towards solving a common problem.

Compared with the political participation typology of Verba, a group of researchers, under guidance of Jan Teorell from sweden, expanded the concept of participation to five dimensions and included the already mentioned consumer participation and protest activities (demonstrations, strikes, pickets, etc.) as a dimension of political participation (Teorell et al., 2007).

To identify the factors that explain the unequal attitudes of citizens to involvement in the participation process, a team of British researchers, guided by Gerry Stoker and based on empirical studies, developed a model called CLEAR (Stocker, 1996). The name is coined from the first letters of the words that represent the key principles of participation. The researchers identified five key factors of the participation process.

The most effective participation is possible when the population:

- can participate - this is determined by resources and knowledge for participation;

- likes to participate - this is a sense of affiliation that strengthens participation;

- is enabled to participate - this is a provision of participation opportunities;

- is asked to engage - the population is approached by official administration institutions or groups of non-governmental organizations and communal organizations;

- is responded to - the population sees that its opinions are taken into consideration.

According to the CLEAR model, participation is assessed in five principal research directions:

- Capacity required for citizen participation - resources, knowledge, skills;

- How weak/strong is a citizens' sense of affiliation to a place/community where they live and what the impact factors are; 
- The legal and institutional framework of a local government for the development of participation democracy and how actively the local civic society interacts with the local power;

- Forms of participation and how often a local government improves the local policy and services provided;

- Evaluation is given by the population to the participation opportunities and the mechanisms offered.

\section{Involvement of citizens of Latvia in the activities of local governments}

Latvia has a necessity to develop and to involve more citizens in different social activities as a member country of the EU as it has a comparably short experience in democratic processes. The opportunities to participate in the European Parliament's elections and to promote the resolution of common issues or questions specific to the country can be one of the forms in which one can express life priorities. The experience of democracy based on the main values of national State is relatively short in Latvia. Three periods of development of Latvian democracy can be observed. The first period involved the creation of understanding of democracy and participation due to two influences: first the development of ideas of Enlightening (Sciècle des Lumières) in the $18^{\text {th }}$ century with Baltic-GermanFrench influences and second - Latvia's own national ideas of self-determination developed in the $19^{\text {th }}$ century in the movement of "new-Latvians" when the involvement and participation of citizens is treated as an honourable duty. The second period is related to the establishment of a National State Republic of Latvia in 1918 when it was necessary to build the State itself with the addition of all necessary attributes for an independent state and enthusiastic participation of citizens is considered to be a pride because for the first time in history, the inhabitants of the country were deciding the destiny of their own state. This logical and step-by-step development of democracy and participation was interrupted not only by abnegation of independence but with an abnegation of the values of democracy because after the Second World War, Latvia (as well as two other Baltic States: Estonia and Lithuania) was incorporated in another State, the Soviet Union. The USSR with its non-democratic regime and the planned economy of orders was halting all kinds of initiatives and was proposing a false image of imitated democracy. For this reason, the restitution of national independence in 1991 was related with the renaissance of ideas of democracy and the development of the participation of citizens in all kinds of activities, local governments included.

Participation at its highest level is to be implemented at the administrative level of local governments, i.e. the involvement of citizens in work of committees, working groups, advisory boards of the local governments where administrative decisions are taken or questions to political institutions of the local governments - standing committees of councillors and meetings of a city or municipality councils are prepared.

\begin{tabular}{|c|cccc|}
\hline \multicolumn{1}{|l}{$\begin{array}{l}\text { Table 1: Opportunities and form of citizen participation in the decision-making process in local } \\
\text { governments in Latvia }\end{array}$} & $\begin{array}{c}\text { Information, } \\
\text { availability and } \\
\text { freedom of } \\
\text { information }\end{array}$ & \begin{tabular}{c} 
Consultations \\
\hline Political level
\end{tabular} & $\begin{array}{c}\text { Participation } \\
\text { in decision- } \\
\text { making }\end{array}$ \\
\cline { 2 - 5 } & Council & + & + & - \\
\hline $\begin{array}{c}\text { Administrative } \\
\text { level }\end{array}$ & $\begin{array}{c}\text { Standing committees } \\
\text { Working groups, }\end{array}$ & + & + & - \\
\hline
\end{tabular}

Source: A summary of participation opportunities developed by L. Seimuskane using both a regulatory framework and actual practice in local governments

The primary places in this system of values are taken by personal values (such as family) but one very important part of this system is related to national independence and the existence of one's own State 
- even such values as personal freedom, human rights or self-realization should be seen as a part of national independence (if we are seeing those values in the historical context of Latvia -to finally come back to the independent state in which each one is not only a citizen but a real participant). In this case it is important that the opportunity to participate in the activities of local governments is considered as a value as well.

The development of different kind of initiatives for Latvian citizens is related with changes in the system of values. As the surveys show, the main values for Latvians are traditional.

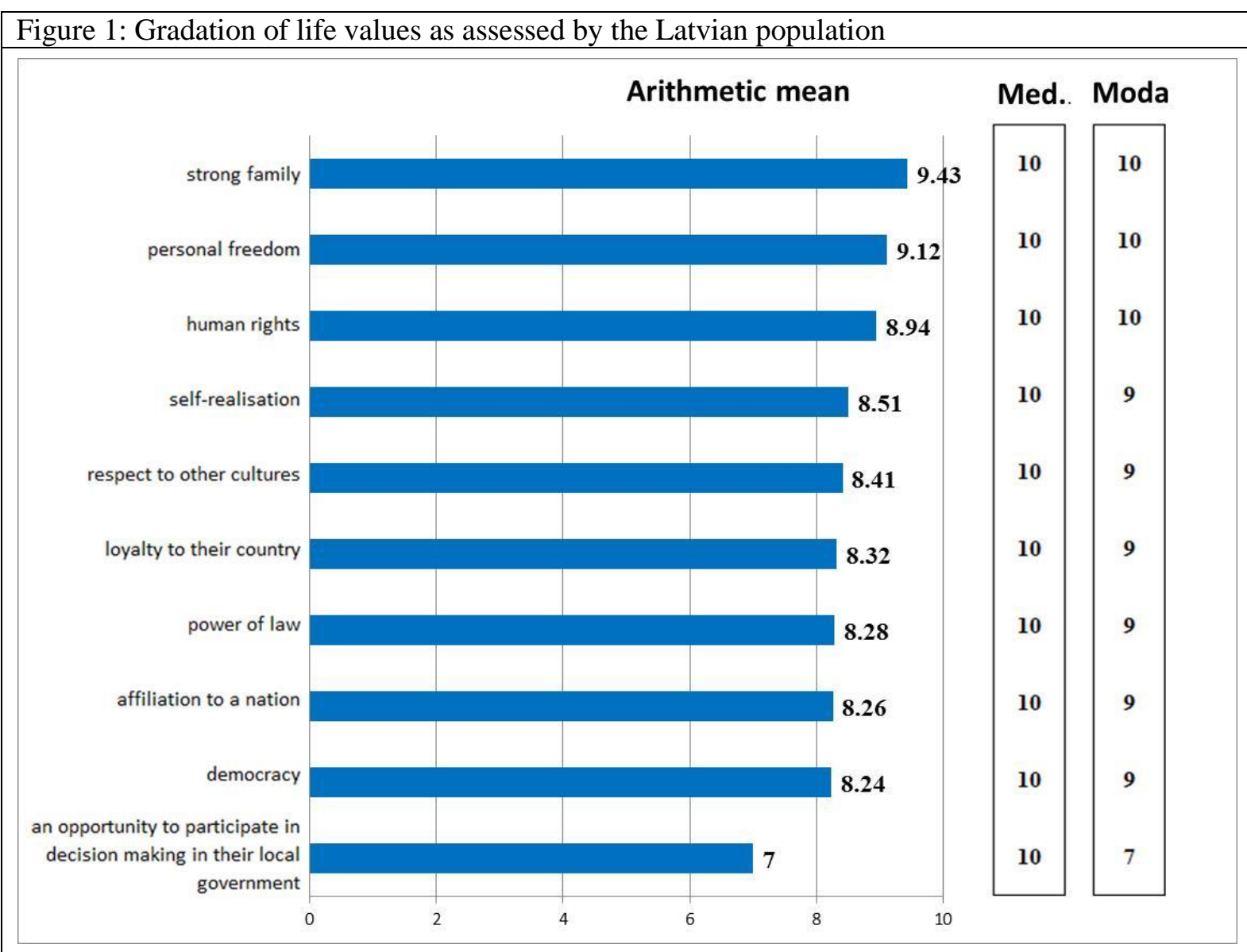

Source: a survey of Latvian population carried out by L.Seimuskane and SKDS in 2012, value scale $1-10(n=1050)$.

Comparing the development of participation concepts in general and their implementation in the realities of Latvia, the authors of this paper are proposing the following scheme: (Table 2)

As we can see, the participation of Latvian citizens is faster because of the need to join the community of democratic countries of the EU - to catch up to the previous development of participation in a shorter period, starting since the 90`s with the reestablishment of the national state.

\section{Regional development and the factors influencing the participation of citizens in Latvia}

The participation of citizens of Latvia in elections differs. First, the participation in the election of European Parliament: the highest activity in this election was in the municipalities of Ikškile (41\%) and Carnikava (41\%). Both municipalities are near Rìga, the capital of the country. The authors consider that this is reasoned by a combination of two factors. First, there has traditionally been a higher voter turnout (for local government as well) in both regions, than the average in country. An additional factor of turnout in the EP election possibly was the fact that there were four persons among the EP candidates who had their registered place of residence in these regions, thus mobilizing local supporters of the candidates.

Here it is important to mention the unequal and unbalanced development of regions in Latvia. First, more than one third of inhabitants of Latvia live in the capital - Riga, and the majority of economic activities and investments, both local and foreign, are concentrated there. Second, an important part of 
the population lives in a reachable distance from the capital, Rīga $(50 \mathrm{~km}$ from Rīga in case of Sigulda, $40 \mathrm{~km}$ in case of Saulkrasti etc.) or on the borders of the capital itself (Ādaži, Babīte, Mārupe etc.) but in all of those cases the majority of people exert their economic activity in Rìga. Third, all other regions of Latvia have towns as regional centers with their own economic activities, but the density of the population is much lower.

\begin{tabular}{|c|c|c|}
\hline Time period & Main processes of participation & Particularities in Latvia \\
\hline $1940 s-1950 s$ & $\begin{array}{l}- \text { voting as active electoral } \\
\text { participation }\end{array}$ & $\begin{array}{l}\text { - passive voting without electoral } \\
\text { activities }\end{array}$ \\
\hline \multirow[t]{4}{*}{$1950 \mathrm{~s}-1970 \mathrm{~s}$} & - participation between the elections: & - \\
\hline & 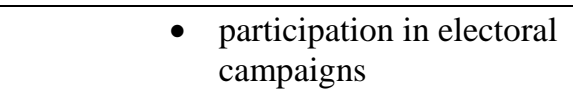 & \\
\hline & $\begin{array}{l}\text { Contacts with deputies } \\
\text { and public servants }\end{array}$ & \\
\hline & - Development of social movements & - \\
\hline $1970 s-1980 s$ & $\begin{array}{l}\text { - Development of new forms of } \\
\text { participation outside of institutions } \\
\text { - protests and abnegations }\end{array}$ & - \\
\hline $1980 s-1990 s$ & $\begin{array}{l}\text { Development of citizens society, } \\
\text { voluntary associations }\end{array}$ & - \\
\hline \multirow[t]{4}{*}{$21^{\text {st }}$ century } & $\begin{array}{l}- \text { rise of different dimensions of } \\
\text { political participation: }\end{array}$ & $\begin{array}{l}- \text { rise of different dimensions of } \\
\text { political participation: }\end{array}$ \\
\hline & $\begin{array}{l}\text { Participation of } \\
\text { consumers and } \\
\text { boycotting }\end{array}$ & $\begin{array}{l}\text { - Participation of consumers and } \\
\text { boycotting }\end{array}$ \\
\hline & $\begin{array}{ll}\text { - } & \text { Petitions } \\
\text { - } & \text { Collective/individual }\end{array}$ & $\begin{array}{ll}\text { - } & \text { Petitions } \\
\text { - } & \text { Collective/individual }\end{array}$ \\
\hline & - Traditional and hidden & $\bullet \quad$ Traditional and hidden \\
\hline
\end{tabular}

Source: Authors

Table 3: Local governments with the highest voter turnout in the election of the European Parliament in 2014

\begin{tabular}{|cccc|}
\hline No. & Local governments & Voter turnout (\%) & Region \\
\hline $\mathbf{1}$ & Ikšksile Municipality & 41 & Vidzeme(near Rīga) \\
\hline $\mathbf{2}$ & Carnikava Municipality & 41 & Vidzeme(near Rīga) \\
\hline $\mathbf{3}$ & Mārupe Municipality & 38 & Vidzeme (near Rīga) \\
\hline $\mathbf{4}$ & Saulkrasti Municipality & 38 & Vidzeme (near Rīga) \\
\hline $\mathbf{5}$ & Garkalne Municipality & 35 & Vidzeme (near Rīga) \\
\hline $\mathbf{6}$ & Kcekava Municipality & 35 & Vidzeme (near Rīga) \\
\hline $\mathbf{7}$ & Rīga & 35 & Rīga region \\
\hline $\mathbf{8}$ & Sigulda Municipality & 35 & Vidzeme(near Rīga) \\
\hline $\mathbf{9}$ & Alsunga Municipality & 34 & Kurzeme \\
\hline $\mathbf{1 0}$ & Ādaži Municipality & 34 & Vidzeme(near Rīga) \\
\hline $\mathbf{1 1}$ & Babīte Municipality & 34 & Vidzeme (near Rīga) \\
\hline
\end{tabular}

Source: summary made by the authors using data of the Central Election Commission (CEC) of Latvia

The authors have selected several years to illustrate the situation: the year 2007 was a very favourable year. After Latvia joined EU in 2004, a strong economic growth and development of welfare was observable. The global economic crisis affected the Latvian economy most severely during the years 2009 and 2010, after that, positive economic growth was once again observable. 
As we can see from the table, nonfinancial investment repartition by regions is not equal. The domination of the Riga region is visible before the crisis, during the crisis and during the situation when the economic conjuncture is stable. The Rìga and Pierīga (the area around capital Rìga) regions together represent more than $75 \%$ of all nonfinancial investments in 2015 while their amount is not yet attaining the pre-crisis level. Such concentration of economic activities in the capital of a country and near it in addition with the diminution of the total amount of nonfinancial investments is starting to cause important differences in quality of life.

\begin{tabular}{|ccccc|}
\hline \multicolumn{6}{|l|}{ Table 4: Financial investments in Latvia by regions, selected years } \\
\hline $\begin{array}{|ccccc|}\mathbf{2 0 0 7} \\
\text { before the crisis }\end{array}$ & $\begin{array}{c}\mathbf{2 0 0 9} \\
\text { during the crisis }\end{array}$ & $\begin{array}{c}\mathbf{2 0 1 0} \\
\text { during the crisis }\end{array}$ & $\mathbf{2 0 1 5}$ \\
\hline Latvia & $6971.8 \mathrm{mln} . E U R$ & $4148.8 \mathrm{mln}$. EUR & $3381.2 \mathrm{mln} . \mathrm{EUR}$ & $4505.7 \mathrm{mln}$. EUR \\
\hline Rīga region & $47.66 \%$ & $53.75 \%$ & $46.34 \%$ & $57.81 \%$ \\
\hline Pierīga region & $21.11 \%$ & $10.67 \%$ & $11.38 \%$ & $18.15 \%$ \\
\hline Vidzeme region & $6.31 \%$ & $6.94 \%$ & $9.23 \%$ & $5.20 \%$ \\
\hline Kurzeme region & $10.39 \%$ & $13.41 \%$ & $15.60 \%$ & $8.42 \%$ \\
\hline Zemgale region & $8.28 \%$ & $8.18 \%$ & $9.14 \%$ & $5.77 \%$ \\
\hline Latgale region & $6.26 \%$ & $7.04 \%$ & $8.31 \%$ & $4.65 \%$ \\
\hline
\end{tabular}

Source: calculations made by authors, using statistical data of Central Statistical Bureau of Latvia

Table 5: Average gross wage in Latvia by regions, selected years

\begin{tabular}{|c|c|c|c|c|}
\hline & $\begin{array}{c}2007 \\
\text { before the crisis }\end{array}$ & $\begin{array}{l}2009 \\
\text { during the crisis }\end{array}$ & $\begin{array}{l}2010 \\
\text { during the crisis }\end{array}$ & 2015 \\
\hline Latvia & 566 EUR & 655 EUR & 633 EUR & 818 EUR \\
\hline Rīga region & $113,60 \%$ & $114,81 \%$ & $114,38 \%$ & $113,08 \%$ \\
\hline Pierīga region & $96,11 \%$ & $95,27 \%$ & $95,26 \%$ & $94,13 \%$ \\
\hline Vidzeme region & $77,73 \%$ & $76,95 \%$ & $76,62 \%$ & $78,61 \%$ \\
\hline Kurzeme region & $83,92 \%$ & $83,82 \%$ & $85,94 \%$ & $84,72 \%$ \\
\hline Zemgale region & $81,80 \%$ & $80,31 \%$ & $80,25 \%$ & $83,50 \%$ \\
\hline Latgale region & $69,61 \%$ & $69,62 \%$ & $69,51 \%$ & $68,95 \%$ \\
\hline
\end{tabular}

Source: calculations made by authors, using statistical data of Central Statistical Bureau of Latvia

Analysing the changes of average wage in Latvia, the authors would like to insist that the nominal average gross wage was growing constantly even during the crisis in both the country and in the specific regions (in the most unfavourable regions as well), except for the year 2010. At the same time the dynamics in Latgale, which is the most unfavourable region in Latvia, show a rise in the gap between the wage in the capital and other regions in comparison with Latgale.

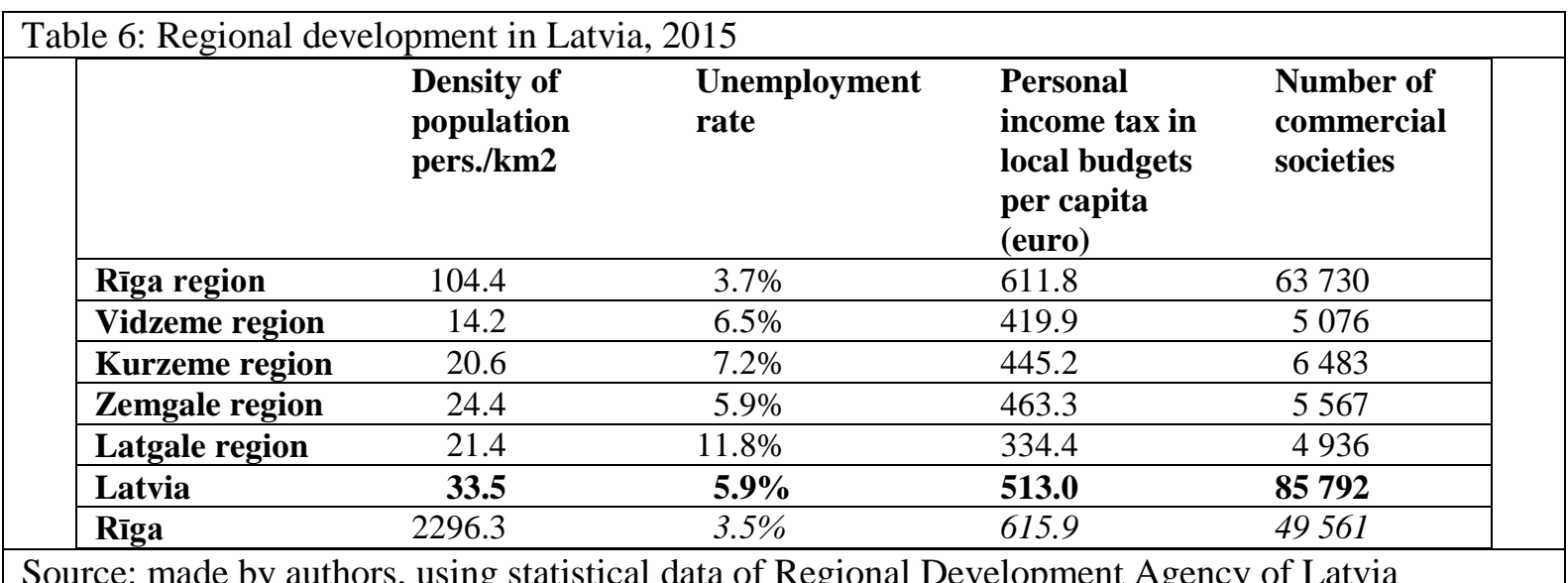

From this data it can be observed that the differences between the regions are important. According to the Latvian legislation, the distribution of income from personal income tax is as follows: $80 \%$ constitutes a part deducted for the budgets of local governments, while $20 \%$ goes towards the national 
state budget. The personal income tax is a significant income source for local governments, reaching almost $85 \%$ of all tax income in their budget and is closely related to the performance of local governments. All reasons (individual, economic, political) that reduce the income from this tax can affect the budgets of local governments, execution of their functions, and territorial development. Personal income tax is distributed according to the registered place of residence of the income recipient. A comparison of income data for personal income tax among local governments shows that the lowest income from this tax is earned by the local governments in the municipalities of Latgale, while the highest by the local governments of municipalities near Riga (or the so-called Pierīga). According to the Latvian tax policy, income tax is distributed rather than by the work place of the income recipient, thus ensuring the municipalities of Pierīga a comparatively high income from personal income tax in their budgets. The system of distributing personal income tax has caused many discussions about the unequal distribution of income among municipalities, ensuring higher budget income for the municipalities of Pierīga than for those local governments who provide work places to residents of the relevant local governments.

In cooperation with the Marketing and Public Opinion Research Centre, SKDS, a survey of Latvian residents was made from 13 July 2012 to 24 July 2012. For the study, a direct interview at a place of residence of respondents was used. By using stratified random sampling, 1050 permanent residents of Latvia aged 15 to 74 were surveyed, which is a representative selection for the general population. The survey comprised all Latvian regions. Most questions were measured in a scale of 10 points, where $\mathbf{1}$ is a categorical refusal and $\mathbf{1 0}$ - absolute consent. A repeated examination of certain participation questions was carried out by the author in cooperation with the SKDS from 15 November to 27 November 2013 and from 28 November to 12 December 2014. Technical information of the research is the same, while the number of respondents differs - in 2013, 1045 respondents were interviewed, while in 2014, 1003 permanent residents of Latvia were interviewed.

The survey shows that the most determined respondents, who would be ready to protect their interests in relationship with the local government, reside in Vidzeme ( $48 \%$ the arithmetic mean), Zemgale (42\%), and Rīga (40\%), but the respondents of Kurzeme and Pierīga - not so often, 32\% on average. Vidzeme is the only statistical region where the residents in all three years $(2012,2013,2014)$ showed greater determination to be involved in activities when protecting their interests compared to the average index in the country in each survey year.

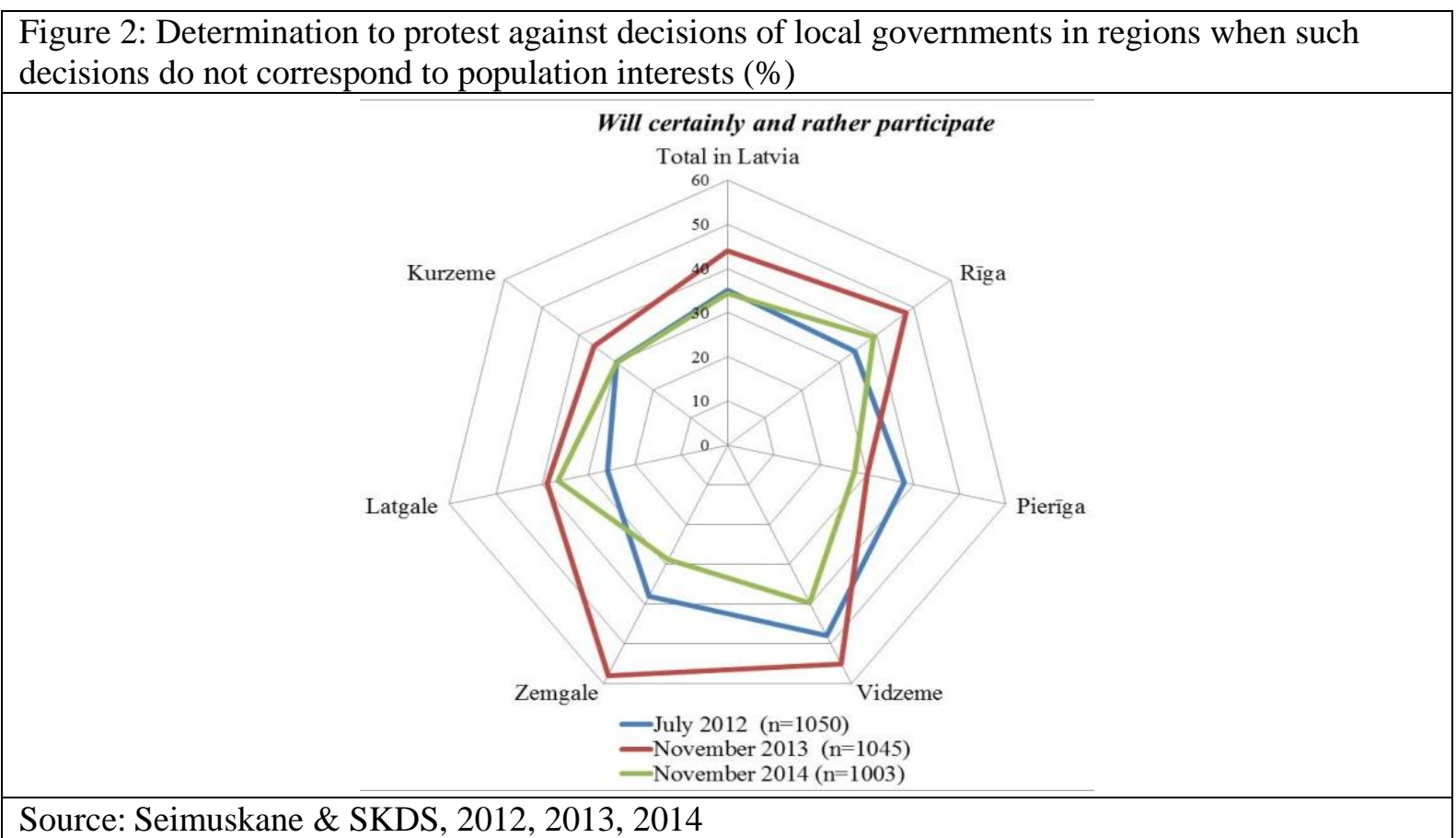

When comparing the respondent activity by regions in all three years, the highest activity was demonstrated in 2013, with the exception of Pierīga where the activity in 2013 was lower (30\%) than in 2012 (38\%). In 2014, the number of the respondents, who would be determined enough to protect 
their interests in relation to the decisions of local governments, reduced in all regions. The smaller decrease in the activity, when compared to 2013, was seen in Latgale (-2\%) and Pierīga (-3\%), while the greatest - in Zemgale (-29\%) and Vidzeme (-15\%). It is significant that Zemgale was the region when a year ago, in 2013, the survey results showed the biggest increase in respondent activity when compared to $2012(+20 \%)$.

Table 7: Respondent opinion on dynamics of participation changes in the decision-making process in their local government, compared to the situation three years ago (\%)

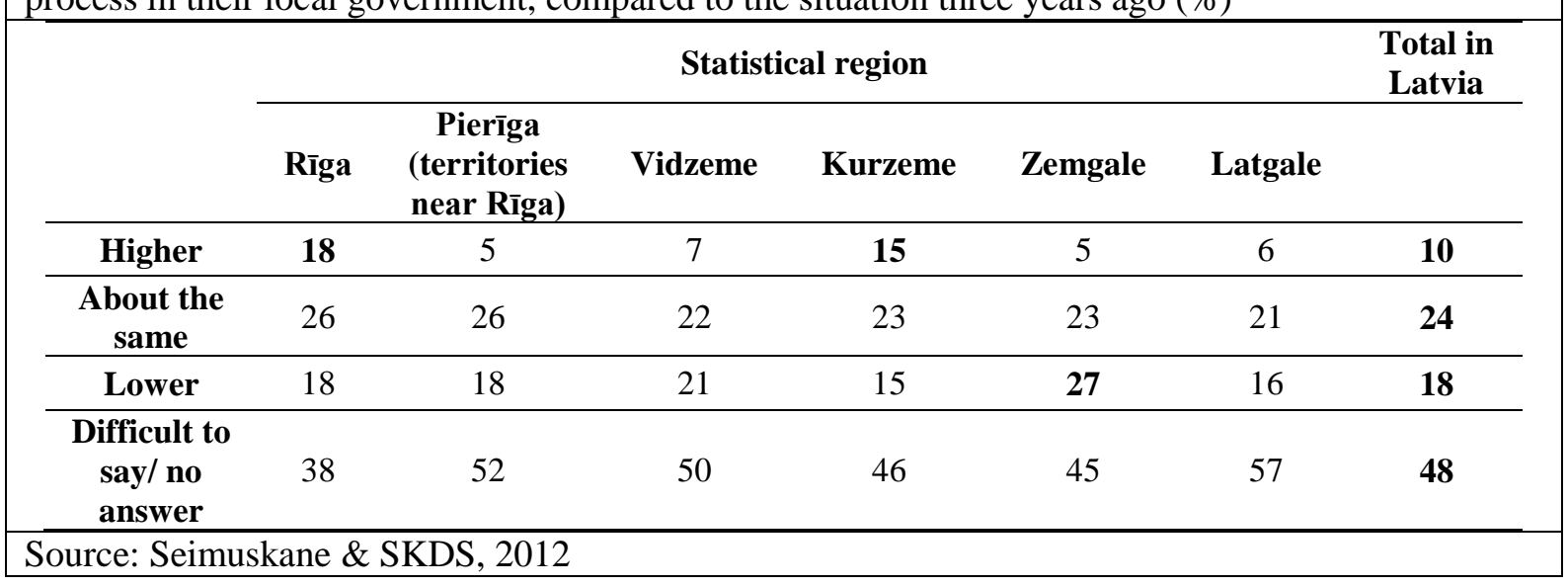

\begin{tabular}{|c|c|c|c|}
\hline Motivation of citizen participation & & $\begin{array}{l}\text { Negative motivation of citizen } \\
\text { participation }\end{array}$ & \\
\hline External factors & & External factors & \\
\hline $\begin{array}{l}\text { Aggravation of problems or } \\
\text { events that make a person to } \\
\text { react and protect his/her } \\
\text { position }\end{array}$ & $14 \%$ & $\begin{array}{l}\text { - disregarding, not listening to, and not } \\
\text { taking into account the population's } \\
\text { opinion }\end{array}$ & $27 \%$ \\
\hline $\begin{array}{l}\text { Visible results of participation } \\
\text { activities }\end{array}$ & $10 \%$ & - Lack of results, changes & $15 \%$ \\
\hline $\begin{array}{l}\text { - listening to opinion of the } \\
\text { population }\end{array}$ & $8 \%$ & $\begin{array}{l}\text { - Decision making is more distant from } \\
\text { the population in regional centres, and } \\
\text { this is a consequence of the } \\
\text { administrative and territorial reform }\end{array}$ & $9 \%$ \\
\hline $\begin{array}{ll}- & \text { solving of problems of the } \\
\text { population }\end{array}$ & $6 \%$ & $\begin{array}{l}\text { - Emigration of young active people and } \\
\text { low activity of elderly }\end{array}$ & $8 \%$ \\
\hline $\begin{array}{ll}\text { - } & \text { positive changes to } \\
\text { representation of the local } \\
\text { government }\end{array}$ & $6 \%$ & & \\
\hline Individual factors & & Individual factors & \\
\hline - $\quad$ Increasing individual activity & $17 \%$ & $\begin{array}{l}\text { - Distrust of population in councillors, } \\
\text { local government, state }\end{array}$ & $11 \%$ \\
\hline - $\quad$ A wish for changes & $11 \%$ & - Apathy, depression, laziness & $11 \%$ \\
\hline $\begin{array}{l}\text { Increasing self-confidence, } \\
\text { courage, conviction, } \\
\text { information awareness }\end{array}$ & $10 \%$ & $\begin{array}{l}\text { - Small interest about process in their } \\
\text { local government }\end{array}$ & $6 \%$ \\
\hline $\begin{array}{l}\text { - Increasing interest about the } \\
\text { current processes }\end{array}$ & $7 \%$ & & \\
\hline
\end{tabular}

The authors of this paper would like to emphasize to several reasons for the changes. First, it is necessary to consider that the changes in opinions (optimistic or pessimistic vision) are closely related to the changes in economic situation in the country. The survey was made just after the crisis. It is important to remember that Latvia was a country which suffered a lot during this crisis and economic difficulties affected the welfare of the population a lot (before the crisis Latvia had the most rapid growth of GDP in EU (+11\% in 2007), the global financial crisis affected the Latvian economy 
strongly (-18\% of GDP in 2009, the changes for employees by professional groups in 2010 in comparison with 2008 showed loses of $-33 \%$ for specialists and $-35 \%$ for qualified workers) (Central Statistical Bureau of Latvia). Those changes are reflected in the situation of income in the possession of households, their housing, and their perception of well-being. Second, those changes in the economic situation in general have an impact on the possibilities of local government to react to the needs of citizens due to the financial means in their possession (income tax paid in local budgets).

The authors of this paper would like to insist that the latest statistical data (the survey made by SKDS in February 2017) show the same tendencies: first, with the development of economic activities and with the growth of welfare the satisfaction with local government activities is observable everywhere, even in the less developed region of Latvia - Latgale shows the satisfaction of citizens ( $8 \%$ fully satisfied and $49 \%$ almost satisfied), the average satisfaction level in Latvia is 52\%; second, the most satisfied citizens are in Rìga where the local government has the most financial means at their disposition. If we are comparing the development of the participation of citizens and their satisfaction with the concepts of the Welfare State (Pigou, 1920), the idea that the perception of happiness is closely related with the economic welfare of citizens is fully confirmed in the case of Latvia.

Main conclusions are:

- the participation of citizens is more active in local government activities than in European Parliament elections due to faster and more visible results in solving problems,

- the global financial crisis strongly affected the participation level,

- a misbalance in regional development, including in terms of quality of life, is reflected in the level of participation because, a higher level of participation is observed in economically favourable regions.

\section{References}

Central Statistical Bureau of Latvia. (2013) Self-assessments of Latvian Local Governments in 2013, Rīga.

European Charter of Local Self-Government (1985., October 15), Treaty Nr122.

Leta news (February, 2017). Aptauja: Puse iedzīvotāju kopumā apmierināti ar savas pašvaldības darbu. (Survey: Half of the population are satisfied with the work of their municipality). Available online: https://www.tvnet.lv/4587007/aptauja-puseiedzivotaju-kopuma-apmierinata-ar-savas-pasvaldibas-darbu

Pigou A. (1932) The Economics of Welfare. $4^{\text {th }}$ ed., London, Macmillan. (Original publication 1920).

Seimuskane, L., Marketing and public opinion research centre SKDS (2012). Survey of Latvian population - assessment of citizens'participation and democracy in local governments in Latvia.

Seimuskane, L., Marketing and public opinion research centre SKDS (2013). Survey of Latvian population - assessment of citizens'participation and democracy in local governments in Latvia.

Seimuskane, L., Marketing and public opinion research centre SKDS (2014). Survey of Latvian population - assessment of citizens'participation and democracy in local governments in Latvia.

Seimuskane, L., Vilka, I. (2013) Relations between citizens' trust and participation in local governments in Latvia. In: The 21.st NISPAcee Annual Conference: Regionalization and Inter-regional Cooperation. Serbia, Belgrade, May 16-18, 2013. NISPAcee Press.

Stoker, G. (1996) The Decline of Citizen Engagement? In: Why politics matters making democracy work. Palgrave Macmillan, 87-102.

Teorell, J., Torcal, M., Montero J., R. (2007) Political Participation: Mapping the Terrain. In: Citizenship and Involvement in European Democracies: A Comparative Analysis, eds. Jan W. Deth, Jose Ramon Montero, Anders Westholm. London and New York: Routledge, (Vol. 17) 334-357.

Van Deth, J., W. (2001) Studying political participation: Towards a Theory of Everything? Introductory paper prepared for delivery at the Joint Sessions of Workshops of the European Consortium for Political Research Workshops Electronic Democracy: Mobilisation, Organization and Participation via new ICTs.

Verba, S., Nie, N., Kim, J. (1978) Participation and Political Equality: A Seven-Nation Comparison. Chicago: Chicago University Press.

\section{Data Bases}

Central Election Commission of Latvia: www.cvk.lv

Central Statistical Bureau of Latvia: www.csb.gov.lv

State Regional Development Agency of Latvia: www.vraa.gov.lv 